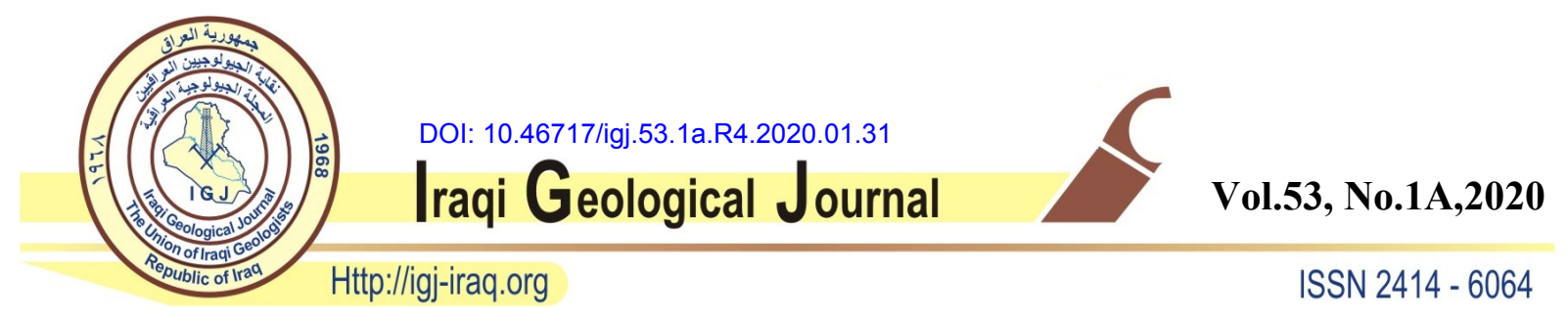

\title{
GEOLOGICAL MODEL OF HARTHA FORMATION IN MAJNOON OILFIELD, SOUTHERN IRAQ
}

\author{
${ }^{1}$ Gheed C. Abd Aoun* and ${ }^{2}$ Thamer A. Mahdi \\ ${ }^{1 \& 2}$ Department of Geology, College of Science, University of Baghdad, Baghdad, Iraq \\ *E-mail: Gheed.alghanemy@yahoo.com
}

Received: 8 August 2019; accepted: 15 September 2019

\begin{abstract}
This study aims to construct a 2D geological model for Hartha Formation in Majnoon oil field based on well logs data from eight wells (Mj-1, Mj-3, Mj-10, Mj-11, Mj-15, Mj-16, Mj-20 and Mj-33), core and cutting samples. Petrophysical properties (effective porosity and water saturation) are derived from CPI interpretation of well logs while facies associations are interpreted through the study of microfacies analysis of thin sections for core and cutting samples. By using RockWorks16 software, 2D facies and petrophysical model are built to estimate the vertical and lateral variation of these properties. The $2 D$ facies models display the dominance of outer ramp facies in the lower part of Hartha Formation, whereas mid-ramp, shoal, and inner ramp facies associations occupy the upper part. The shoal facies has a wide and continuous extent, which is characterized by high effective porosity and low water saturation. Therefore, it represents the most important reservoir of Hartha Formation in Majnoon oilfield. Other facies have less reservoir quality due to low porosity and high water saturation. Besides, their occurrence in deeper structural depths. Based on the output of the $2 D$ effective porosity model, the porosity increased upward the succession of Hartha Formation as a result of the transition from outer ramp to shoal or inner ramp facies. Accordingly, the water saturation model shows low values at upper parts of the anticline structure of Majnoon oil field, which indicates high hydrocarbon saturation at the upper parts of Hartha Formation.
\end{abstract}

Keywords: Hartha Formation; Majnoon oilfield; Geological modeling; Porosity; Water Saturation

\section{INTRODUCTION}

Hartha Formation includes important carbonate reservoirs that are producible in Central and Southern Iraq. It is acquired its importance because of the presence of quantities of 
hydrocarbon, and this due to the petrophysical characteristics (Dunnington and Morten, 1953). Hartha Formation was defined by Rabinit in 1952 from well Zubair-3, south of Iraq (Owen and Nasir, 1958), where it is composed of organic detrital, glauconitic limestones, with grey and green shaly interbeds (Jassim and Goff, 2006). The thickness of Hartha Formation is changing, mainly because the formation is passing into both laterally and vertically with the marly limestones of the Shiranish Formation. The average thickness of the formation in south Iraq ranges between $200-250 \mathrm{~m}$, and in northern Iraq the thickness up to $350 \mathrm{~m}$ (Buday, 1980). The upper contact of Hartha Formation is conformable with the Shiranish Formation while the lower contact of the formation is unconformable with the Sadi Formation and is often marked by conglomeratic basal beds (Jassim and Goff, 2006).

The true distribution of petrophysical properties in reservoir units is a result of different processes such as diagenesis and facies change. It is possible to interpret and capture the extent of these processes within a reservoir but remains how the distribution of petrophysical properties unknown. So the constructions of geological models that simulate the physically significant features somewhat illustrate how these characteristics are distributed (Pyrcz and Deutsch, 2014). Constructing reservoir models has become a significant step in resource development as reservoir modeling provides a spot to integrate and compile all available data and geologic concepts. The successful application of these reservoir models is used to calculate reserves of hydrocarbon and to predict their presence in places where there are no drilled wells (Philip Ringrose, 2015). This study deals with the construction of twodimensional models for Hartha Formation in Majnoon oil field by using RockWorks software (2016). The geological model is built for facies and petrophysical properties (effective porosity and water saturation). Where the petrophysical properties were studied and deduced through Computer Processing Interpretation (CPI) by using Interactive petrophysics (IP) software, while facies association for the formation taken from microfacies analysis for core and cutting samples.

Many studies were carried on Hartha Formation which described the reservoir quality, stratigraphy, and depositional environment, such as Al- Sadooni, in 1996 divided Hartha Formation into five microfacies in Central Iraq and Al-Sammarai (2010) studied the Petrophysical reservoir properties of Hartha Formation in Balad Oil Field, Salah Al-Dain Area, and Central Iraq. Also, Al-Zaidy et al. (2013) studied the reservoir properties of Hartha Formation also studied the sequence stratigraphy for the formation in Ahdab oilfield and Al-Kilaby (2017) studied the sequence stratigraphy and reservoir characterization of the Hartha Formation, southern Iraq. 


\section{LOCATION OF THE STUDY AREA}

The study area is located in Majnoon oilfield, southern Iraq. It is about $60 \mathrm{~km}$ from Basrah Governorate, near the Iraqi-Iranian borderlines (Fig.1). The selected wells in this study include $(\mathrm{Mj}-1, \mathrm{Mj}-3, \mathrm{Mj}-10, \mathrm{Mj}-11, \mathrm{Mj}-15, \mathrm{Mj}-16, \mathrm{Mj}-20$ and $\mathrm{Mj}-33)$.

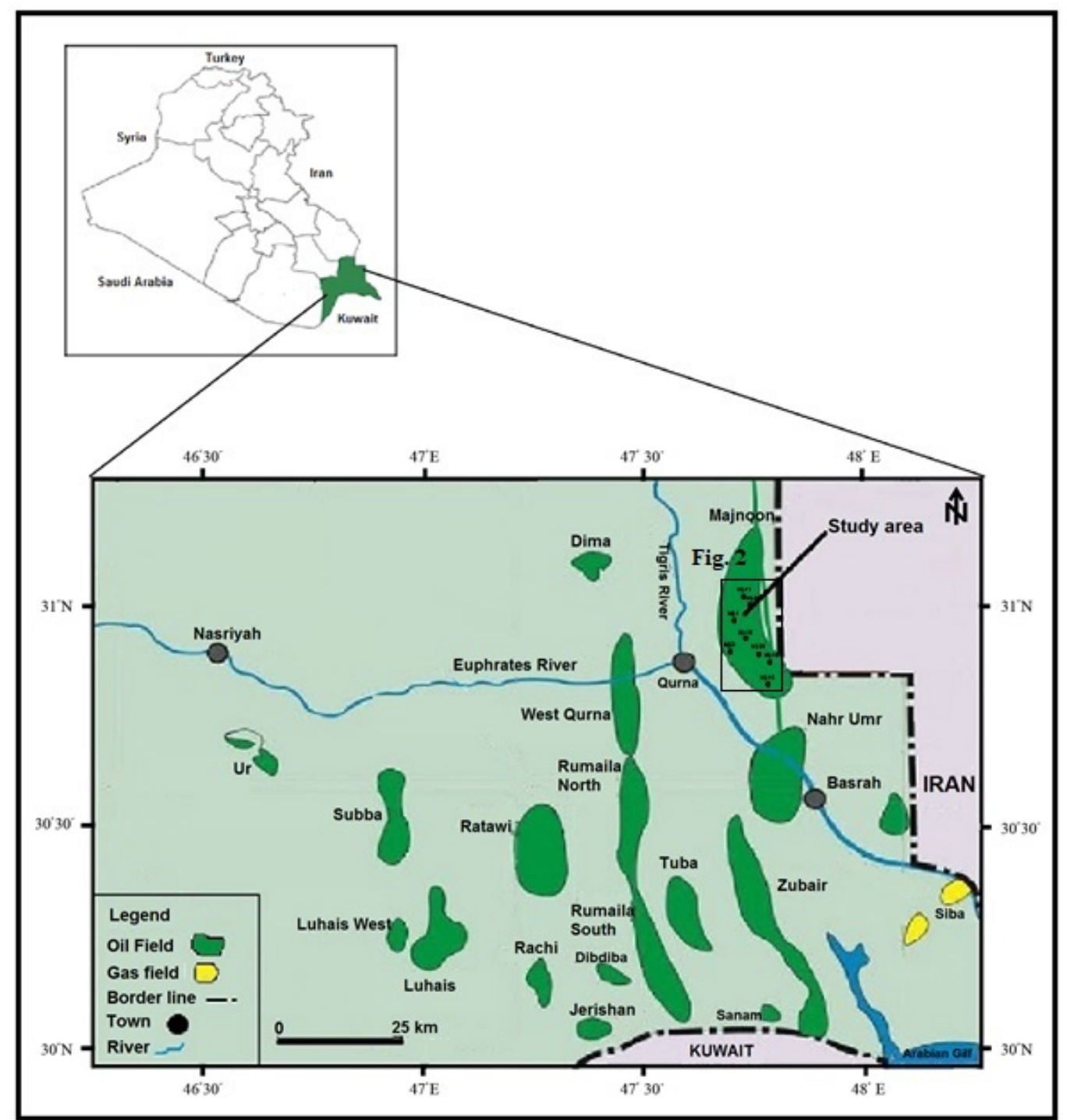

Fig.1: Location map of the study area (Al-Khafaji et al., 2017)

\section{GEOLOGIC SETTING}

Majnoon oilfield is located within the unstable shelf in Mesopotamian Zone (Zubair Subzone), according to the tectonic subdivision of Iraq (Jassim and Goff, 2006). The trend of the structures in this tectonic unit was influenced by the geometry of the underlying basement blocks and faults (Buday, 1980). The structural trend of Hartha Formation represented by an elongated anticline that has approximately an NW-SE trend (Fig.2). 


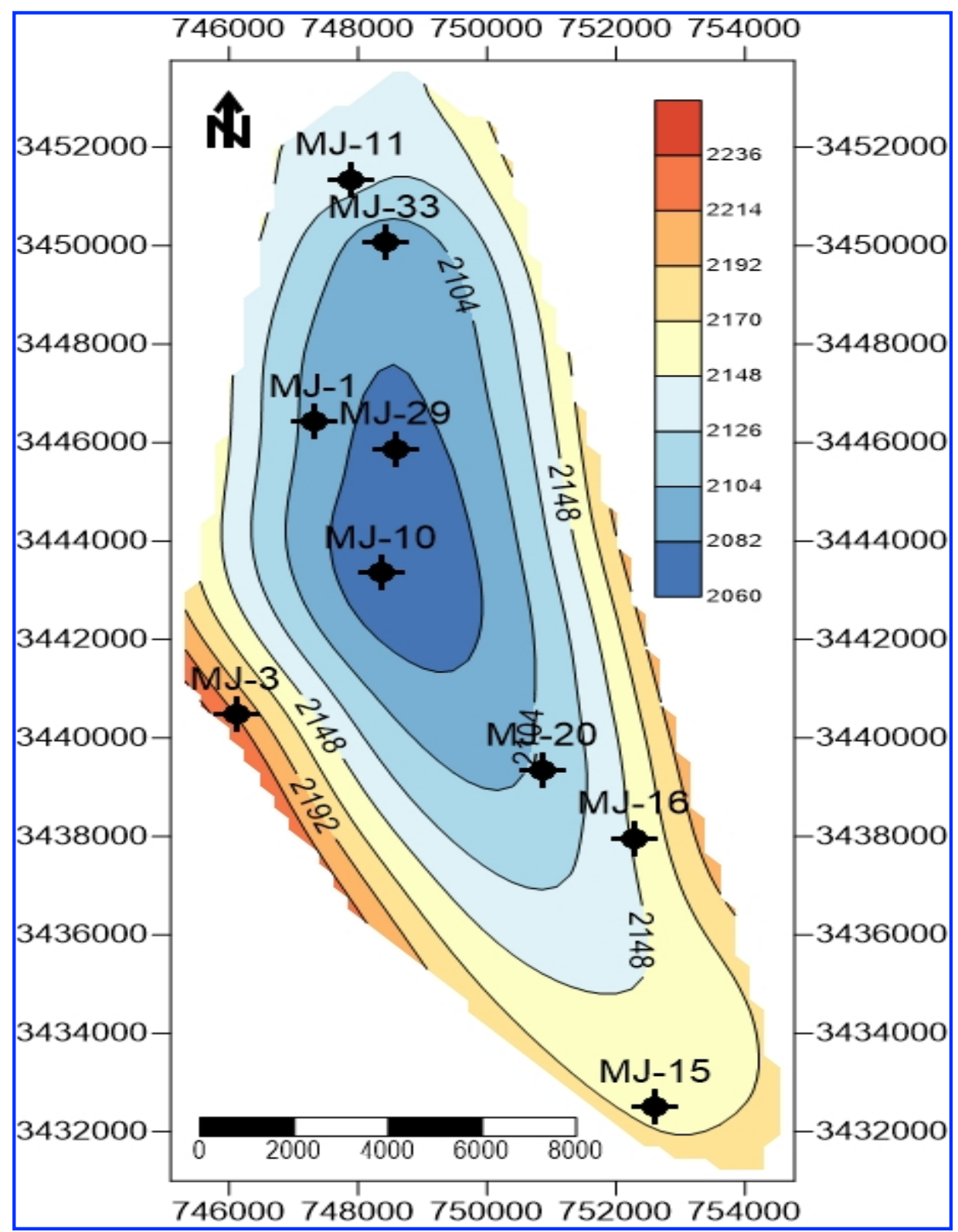

Fig.2: Structure contour map at top of Hartha Formation

\section{PROPERTY MODELING}

Property modeling includes establishing facies and petrophysical model and explains their distribution between available wells in a way that maintains the homogeneity of the reservoir and conforms to the wells' data (Schlumberger, 2010). The property modeling in this study is two-dimensional for the Hartha Formation. The models are built for each reservoir unit, and through two directions as shown in Figure (3). The first correlation direction includes wells ( $\mathrm{Mj}-1, \mathrm{Mj}-10, \mathrm{Mj}-15, \mathrm{Mj}-16$ and $\mathrm{Mj}-20)$, where the second includes the wells $(\mathrm{Mj}-1, \mathrm{Mj}-3, \mathrm{Mj}-11$ and $\mathrm{Mj}-33)$. 


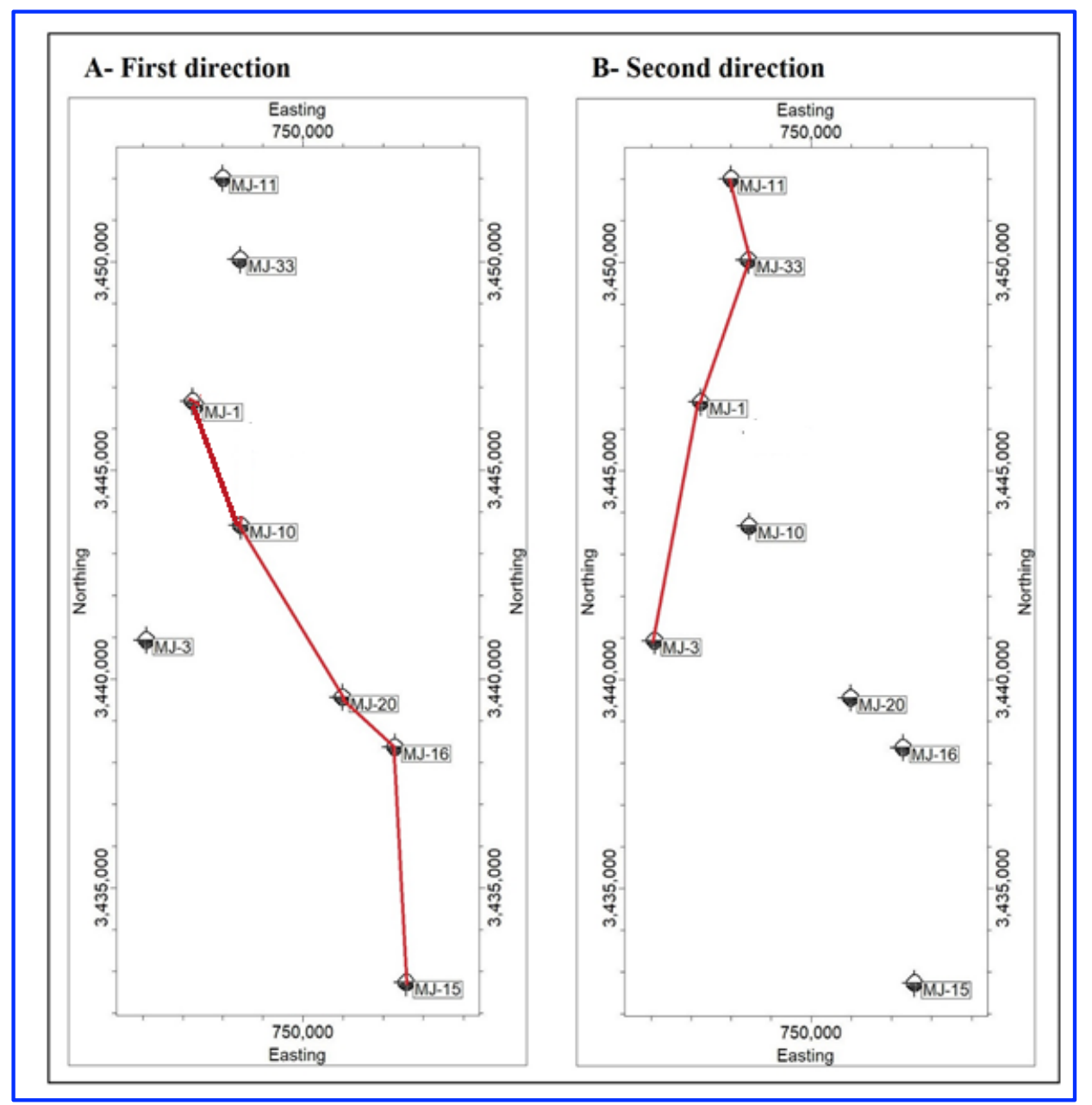

Fig.3: Location map of the study wells with the directions of correlation sections property modeling

\section{FACIES MODEL}

Facies modeling is used to represent the distribution of discrete facies of formation rocks, which represents the depositional environment of this formation (Yuliandri et al., 2014). Facies modeling is often important in reservoir modeling because the petrophysical properties such as porosity and saturation are highly correlated with facies type (Pyrcz and Deutsch 2014). Two dimensional facies model is generated by using Rock Works software 16. The modeling includes importing I- data (Interval data) that belong to facies associations of Hartha Formation. The facies model shows the lateral distribution of facies association of Hartha Formation (Figs. 4\&5). In both sections, the lower part of Hartha Formation is dominated by outer ramp facies, whereas other facies associations (mid-ramp, shoal, Inner ramp) occupy the upper part (Figs. 4\&5). The shoal facies makes the main reservoirs in Hartha Formation that have different thickness and found in the crest and flanks of Majnoon oil field structure (Figs. 4\&5). Therefore, these facies form combined trap in the field. 


\section{PETROPHYSICAL MODEL}

Petrophysical modeling is the process of assigning petrophysical properties values, the important petrophysical properties used in modeling are porosity and water saturation. They are the main variables needed for reservoir characterization which are modeled within each facies and reservoir layer (Pyrcz and Deutsch 2014). Well log data provide precise information on the porosity and water saturation which are obtained from computer processing interpretation using IP software for building 2D petrophysical models in this study. This is done by importing CPI results as P-data (Point data) in RockWorks software.

\section{Porosity Model}

Porosity models are used directly to assess pore volume and to predict and to know the distribution of porosity in areas where there are no wells. Affected porosity is calculated and interpreted using the IP software depending on the results of porosity logs (density, neutron, and sonic logs). 2D cross sections in two directions are built to explain how to distribute effective through and between study wells. The effective porosity model shows that the highest porosity values lie in the upper parts of Hartha Formation, whereas they decrease downward the succession (Figs. 4\&5). This trend is attributed to the dominance of shoal facies at the upper parts of the formation that overly outer- and mid-ramp facies (Figs. 4\&5).

\section{Water Saturation Model}

The water saturation values derived from IP software are imported into Rock Works software. The 2D model show low water saturation at upper parts of the anticline structure of Majnoon oil field towards wells Mj-1, Mj-10, Mj-11 and Mj-33 (Figs. 4\&5). This implies high hydrocarbon saturation at the same structurally high parts, which coincide with the upper parts of Hartha Formation where shoal facies are dominant (Figs. 4\&5). Therefore, high saturation of water is found in the deeper depths of Majnoon structure (Figs. 4\&5). 


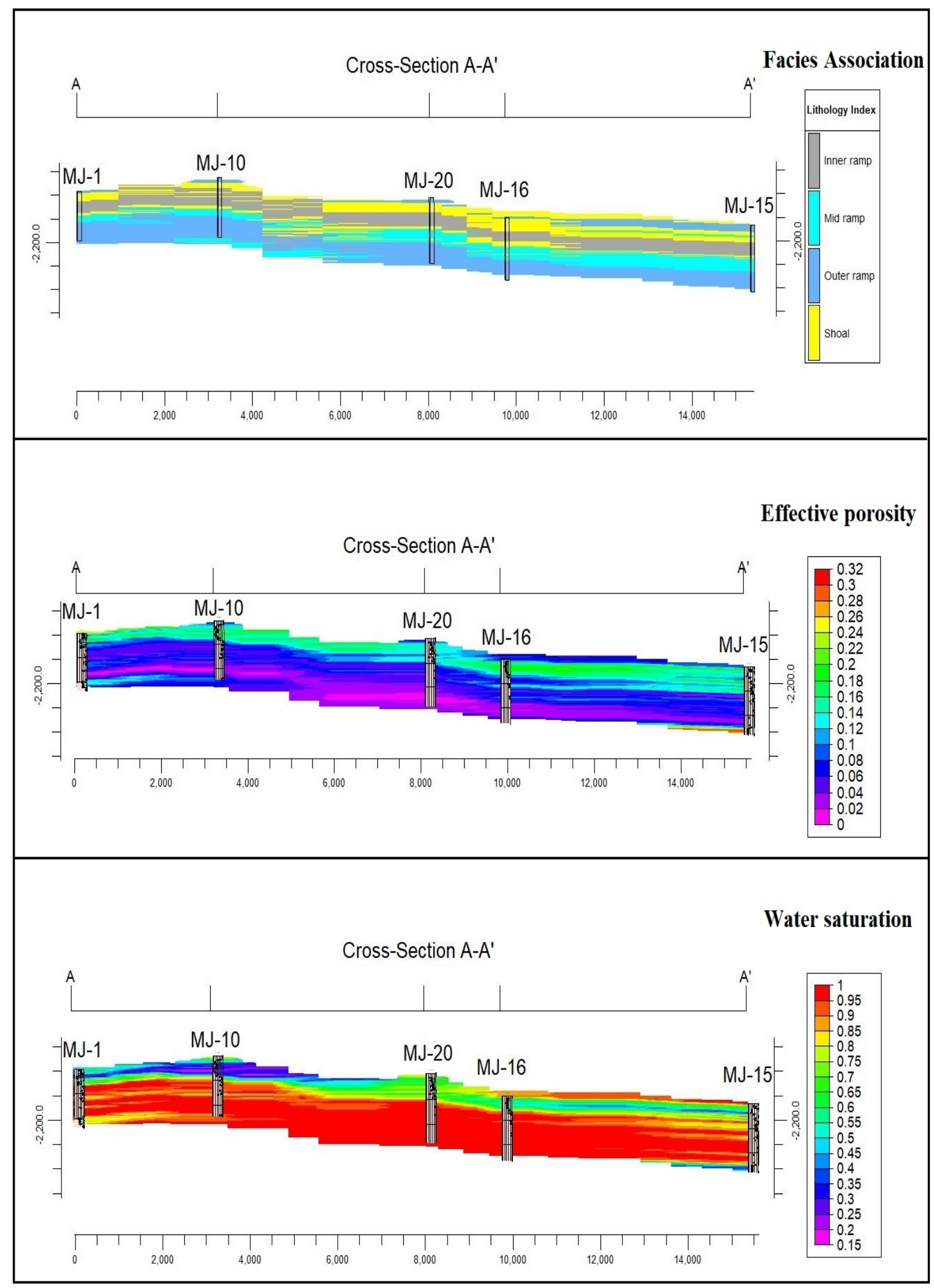

Fig.4: 2D model for facies associations, effective porosity and water saturation of Hartha Formation, section1 


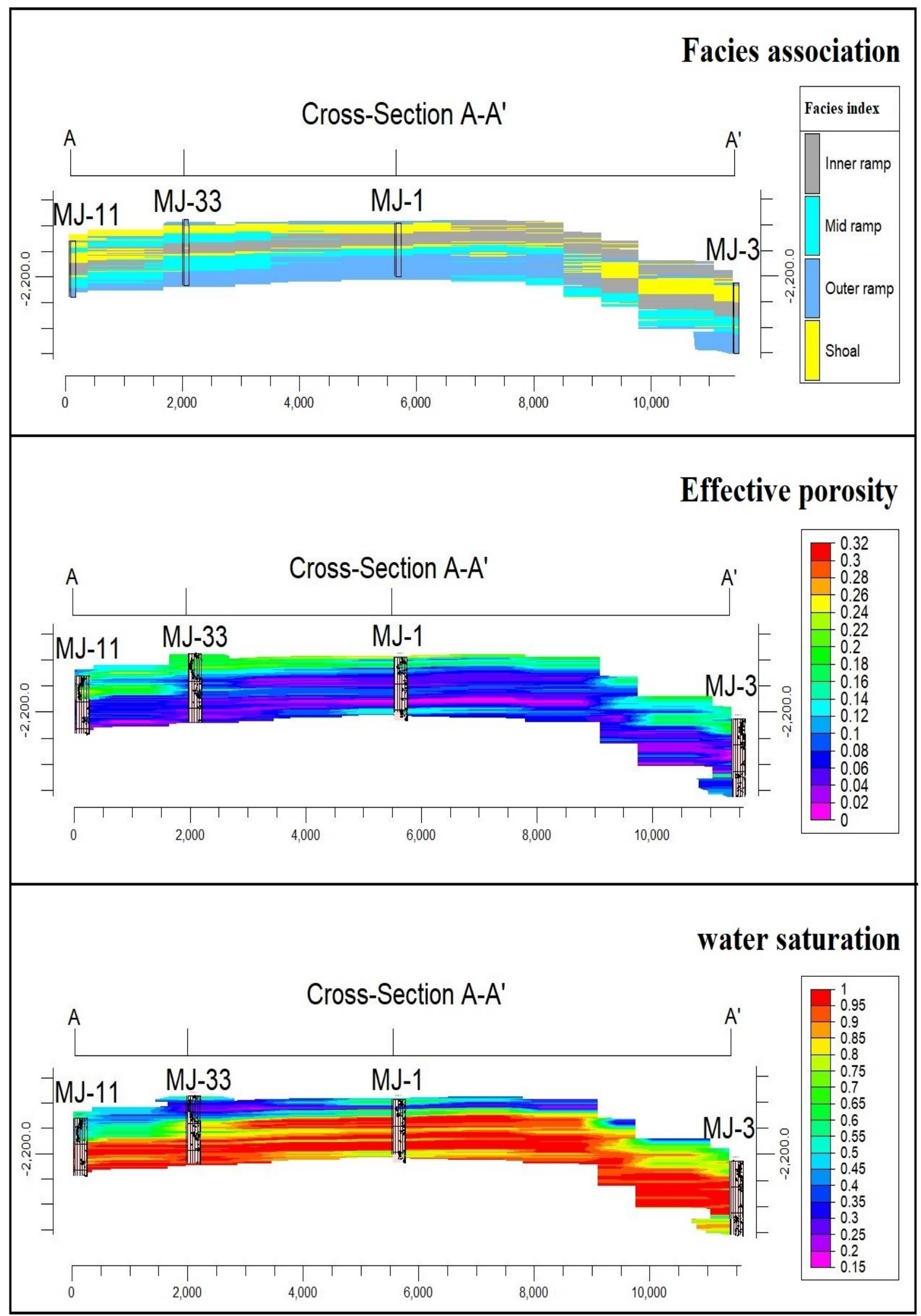

Fig.5: 2D model for facies associations, effective porosity and water saturation of Hartha Formation, section2 


\section{CONCLUSIONS}

1- The use of RockWorks (2016) software shows remarkable vertical and lateral variations in facies, effective porosity, and water saturation of Hartha Formation in Majnoon oil field. These variations are captured among the study wells through modeling of facies and well logs data.

2- Facies model shows the distribution of the depositional environments for Hartha Formation, where mid-ramp, shoal and Inner ramp facies associations occupy the upper part of the formation, while the lower part is dominated by outer ramp facies.

3- Petrophysical properties models are built for effective porosity and water saturation. The effective porosity model displays the increase of values towards the upper parts of Hartha Formation, where shoal facies is common and replaced downward the succession by mid- and outer-ramp facies that have lower effective porosity values.

4- High concentration of hydrocarbon is expected to occur at the upper parts of Hartha Formation as predicted by the water saturation model, which shows low water saturation at the upper parts of the Majnoon oilfield. In contrast, the lower part of Hartha Formation is characterized by high water saturation.

5- Based on 2D models of facies, effective porosity, and water saturation, the shoal facies represents the main reservoir of Hartha Formation. This is indicated by high effective porosity associated with low water saturation, in addition to the wide extent of this potential reservoir in most wells of the Majnoon oil field.

\section{REFERENCES}

Al-Khafaji, A. J., Hakimi, M. H., Najaf. A. A., 2017. Organic geochemistry characterisation of crude oils from Mishrif reservoir rocks in the southern Mesopotamian Basin, South Iraq: Implication for source input and paleoenvironmental conditions. Egyptian Journal of Petroleum. 14pp.

Al-Kilaby, A. J., 2017. Sequence Stratigraphy and Reservoir Characterization of the Hartha Formation, Southern Iraq, Unpublished M.Sc. Thesis, University of Baghdad, 111pp.

Al-Sadooni, F. N.,1996. Stratigraphic and Lithological characteristics of Upper Cretaceous carbonates in central Iraq, Jour. of Petroleum Geology, 19(3):271-288.

Al-Sammarai, Z. S., 2010. Hydrocarbon Prospectively of the Hartha Formation (Upper Cretaceous) in Balad Oil Field, Salah Al-Deen Area, Centeral Iraq, Unpublished M.Sc. Thesis,University of Baghdad, $100 \mathrm{pp}$.

Al-Zaidy, A. A., Sattam, M., Nasir, M. E., 2013. High Resolution Sequence Stratigraphy and Reservoir Characterization of the Hartha Formation in Ahdab Oilfield, Journal of Babylon University, Engineering Sciences, 1(21).

Buday, T., 1980. The Regional Geology of Iraq. Stratigraphy and Paleogeography, Kassab, I.I. and Jassim, S.Z., (eds), Dar Al-Kutib Publ. House, Mosul, Iraq, 445pp.

Dunnigton, H.V. and Morton, D.M., 1953. Cretaceous Oil Prospects Cretaceous Reservoir, INOC, Baghdad, Unpub. Report, 8 pp.

Jassim, S. Z. and Goff, J. C. (edts), 2006. Geology of Iraq. Published by Dolin, Prague and Moravian Museum, Berno, 341pp. 
Michael, J., Clayton, V., 2014. Geostatistical reservoir modeling. Second edition, Oxford University Press, New York, 433pp.

Owen, R.M.S., and Nasir, S.N., 1958. The stratigraphy of the Kuwiat-Basrah area. In: Weeks, G.L. (es). Habitat of oil a symposium. Amer. Assoc. Pet. Geol. Tulsa.

Rabanit, P.M., 1952. Rock units-Basrah area. BPC Report, INOC library, No. BGR 8, Baghdad.

Ringrose, P.h., Bentley, M., 2015. Reservoir Model Design. Springer Dordrecht Heidelberg New York London, 249pp.

Schlumberger, 2010. Reservoir Engineering Course. Schlumberger, 137-177pp.

Yuliandri, I., Mirayanti, M., Ismail, R., Radiansyah, J., Wibowo, R.A., Kurniawan, M., and Latuconsina, M., 2014. Facies (Rock Type) Modeling Using Inverse Static Model Process from Porosity Distribution, Case from Baturaja Formation. Adapted from extended abstract prepared in conjunction with oral presentation AAPG International Conference and Exhibition, Istanbul, Turkey. 